\title{
The use of NIRS for prediction of protein content in residues after incubation in the rumen
}

\author{
J. Kański and Z. M. Kowalski
}

\author{
Cracov Agricultural University, \\ Department of Animal Nutrition \\ Al. Mickiewicza 24/28, 30-059 Kraków, Poland
}

\begin{abstract}
The aim of the study was to investigate the possibility of using Near Infrared Reflectance Spectroscopy (NIRS) for determination of crude protein content in residues after incubation in the rumen. Samples of whole-crop grain silages (oats and triticale) of differing maturities (heading, milk, and milk-dough stages of growth) were incubated in the rumen of cannulated bulls for $2,4,8,16,24,48$, and $72 \mathrm{~h}$. After incubation the bags were rinsed, washed and dried $\left(45^{\circ} \mathrm{C}, 48 \mathrm{~h}\right)$ and $\mathrm{N}$ content was determined chemically in the residues. The NIRS measurements were carried out on dried and ground ( $1 \mathrm{~mm}$ ) silage samples. Samples were scanned in duplicate runs (a second run after rotation of the cup) over the range of 1445-2348 nm with a 19 filter-spectrophotometer InfraAlyser $450 \mathrm{R}$ (Technicon). Spectral data were recorded as $\log 1 / R$ (R-reflectance) with IDAS PC software. Calibration equations were calculated with 3,6 and 9 wavelengths (filters) for three sets: all samples ( 2 cereals $x$ 3 stages of maturity $x 7$ incubation times $x 3$ animals; $n=126)$, A-subset $(n=72)$ for samples incubated for 2-16 h, B-subset for samples incubated for 24-72 h $(\mathrm{n}=54)$.

Based on a calibration for all samples $(n=126$ ), crude protein content could be accurately predicted with R equal to $0.95,0.96$ and 0.97 and SEC equal to $0.46,0.41$ and 0.38 , when 3,6 or 9 wavelengths were considered in the equation, respectively. The precision of prediction increased as the number of wavelengths in the calibration equation increased.
\end{abstract}

KEY WORDS: crude protein, residues after incubation in the rumen, in situ, NIRS

\section{INTRODUCTION}

New systems of protein evaluation of feedstuffs used in ruminant feeding need data on protein degradability in the rumen (RPD). Worldwide, the in situ method is the most widely accepted method of determining RPD. However, the most important disadvantage of this method is the time-consuming analysis of the residues 
(Nocek, 1988). Moreover, the amount of residues is usually too small to perform many different analyses in duplicates (e.g., crude protein, NDF, starch, amino acids etc.)

It has been shown recently that Near Infrared Reflectance Spectroscopy (NIRS) could be used for the analysis of the residues (Reeves at al., 1991; Brehm et al., 1997). For example, Reeves at al. (1991) demonstrated good accuracy of NIRS in determining CP and ADF contents in samples of lucerne and orchardgrass hays after in situ incubation. Better accuracy was observed when dry samples were scanned, compared with wet ones. Considering the differing nature of whole-crop grain silages (W-CGS) than of the above hays, mainly because of higher starch and lower protein contents, it could be interesting to see if the NIRS method could also be useful in the analysis of residues of whole-crop grain silage incubation in the rumen.

The aim of the present study was to investigate the possibility of using NIRS for determining crude protein content in samples of W-CGS after incubation in the rumen.

\section{MATERIAL AND METHODS}

Whole crop grain silage (WCGS) was made of oats and triticale, cut at three stages of maturity: heading, milk and milk-dough. Plants were harvested, chopped and ensiled with microbial inoculant additive (Microsil, $10 \times 10^{9} \mathrm{CFU} \mathrm{g}^{-1} ; 10 \mathrm{~g} \mathrm{~T}^{-1}$ fresh forage) in $100 \mathrm{~L}^{-1}$ plastic containers. Chemical composition was determined on dried $\left(50^{\circ} \mathrm{C}, 48 \mathrm{~h}\right)$ and ground samples using standard methods (AOAC, 1995).

In situ RPD was determined by the method described by Kowalski et al. (2001). Approximately $3 \mathrm{~g}$ of dried samples (ground to pass through a $1.5 \mathrm{~mm}$ screen) were placed in nylon bags (Ankom Products, Fairport, NY, USA), which were then incubated in the rumen of three ruminally-cannulated bulls. Incubations were carried out for $2,4,8,16,24,48$ and $72 \mathrm{~h}$. Three bags per incubation time per animal were used. After incubation the bags were rinsed, washed and dried $\left(50^{\circ} \mathrm{C}\right.$, $48 \mathrm{~h}$ ). $\mathrm{CP}$ content in the residues was determined by the Kjeldahl method ( $\mathrm{N} \mathrm{x}$ 6.25 ) in pooled samples of each incubation time for cach animal.

The NIRS measurements were carried out on dried (as above) and ground ( $1 \mathrm{~mm}$ sieve) whole-crop grain silages. Samples were scanned in duplicate runs (a second run after a rotation of the cup) over the range of 1445-2348 nm with a 19-filter spectrophotometer InfraAlyzer 450R (Technicon) and the results of two runs were averaged. Spectral data were recorded as $\log 1 / R$ (R-reflectance) with IDAS PC software supplied with the instrument (IDAS PC, 1989).

The calibration equations used for determination of $\mathrm{CP}$ content in the residues were derived from the correlation between near infrared spectrum and protein con- 
tent in the residues determined by the Kjeldahl method. All of the equations were calculated with 3,6 and 9 wavelengths (filters) for three sets of data: all samples ( 2 cereals $\times 3$ stages of maturity $\times 7$ incubation times $\times 3$ animals; $n=126$ ), A-subset $(\mathrm{n}=72)$ for samples incubated for $2-16 \mathrm{~h}$, B-subset for samples incubated for 24-72 $\mathrm{h}(\mathrm{n}=54)$. Calculations of calibration equations were performed using stepwise multiple linear regression (IDAS PC, 1989). To avoid overfitting, calibrations for the B sub-set were based only on 3 and 6 filters. For validation of equations, multiple correlation coefficient (R), standard error of calibration (SEC), and standard error of prediction (SEP) were calculated. The equations derived from the $A$-subset data were validated using $B$-subset data and vice-versa (see SEP in Table 1) as well as A-subset or B-subset equations were validated using all sample data (see $\mathrm{SEP}_{126}$ ).

\section{RESULTS AND DISCUSSION}

The CP content ranged from 2.25 to $9.50 \%$ DM. It is worth noting that samples after a longer incubation time in the rumen (B-subset) contained more protein than A-subset. Part of this protein probably comes from microbial contamination of the residues. Because of the high susceptibility of W-CGS protein to degradation in the rumen (Kowalski et al., 2001), resulting in the low content of protein in the

TABLE 1

Precision of prediction of $\mathrm{CP}$ content in the residues after the incubation in the rumen using NIRS

\begin{tabular}{|c|c|c|c|c|c|c|c|}
\hline & \multirow{2}{*}{$\begin{array}{l}\text { Range } \\
\% \text { of DM }\end{array}$} & \multirow{2}{*}{ Filters } & \multicolumn{2}{|c|}{ Calibration } & \multicolumn{3}{|c|}{ Validation } \\
\hline & & & $\mathrm{R}^{\prime}$ & $\mathrm{SEC}^{2}$ & $\mathrm{SEP}^{3}$ & $\mathrm{SEP}_{126}{ }^{4}$ & Bias $^{5}$ \\
\hline \multirow[t]{3}{*}{ All, $n=126$} & $2.25-9.50$ & 3 & 0.95 & 0.46 & - & 0.46 & - \\
\hline & & 6 & 0.96 & 0.41 & - & 0.40 & - \\
\hline & & 9 & 0.97 & 0.38 & - & 0.37 & - \\
\hline \multirow[t]{3}{*}{ A-subset, $\mathrm{n}=72$} & $2.25-4.69$ & 3 & 0.84 & 0.35 & 1.36 & 0.93 & -0.44 \\
\hline & & 6 & 0.90 & 0.29 & 1.71 & 1.14 & -0.44 \\
\hline & & 9 & 0.92 & 0.28 & 1.30 & 0.88 & -0.44 \\
\hline \multirow[t]{2}{*}{ B-subsel, $n=54$} & $3.69-9.50$ & 3 & 0.93 & 0.51 & 0.87 & 0.73 & 0.06 \\
\hline & & 6 & 0.94 & 0.46 & 0.79 & 0.66 & 0.25 \\
\hline
\end{tabular}

I $\mathrm{R}$ - multiple correlation coefficient

2 SEC - standard error of calibration

${ }^{3}$ SEP - standard error of prediction of B-subset using equations derived form A-subset data and vice-versa

${ }^{4} \mathrm{SEP}_{126}$ - standard error of prediction for all samples using equations derived for $\mathrm{A}$ or $\mathrm{B}$ - subset

5 Bias - systematic error in the predicted property values 
residues, this group of feedstuffs is difficult for studying the correlation between near infrared spectrum of scanned samples and protein content.

Of the 19 wavelengths used by the spectrophotometer, the two most important regions of the NIR spectrum for determining the CP content in the residues were 1778-1940 and 2139-2190 nm (not presented in the Table 1). According to Clark et al. (1991) the $2200 \mathrm{~nm}$ region has often been used for nitrogen determination in forages.

The multiple correlation coefficient (R) depended mainly on the number of filters (wavelengths) (Table I). The correlation between values estimated by NIRS and determined by chemical analysis was over 0.90 , except for the $R$ value for $A$ subset when 3 filters were considered $(R=0.84$; Table 1$)$. Increasing the numbers of filters resulted in a higher $R$ value and lower $S E C$ and $S_{126^{\circ}}$ Using 3, 6 and 9 filters, and based on the 126 sample data set, the $\mathrm{CP}$ content in the residues could be estimated with the error of prediction equaling $0.46,0.41$, and 0.38 , which is slightly lower (better accuracy) than obtained by Reeves et al. (1991) for CP in lucerne and orchardgrass hay.

The accuracy of prediction was influenced by the data set. The prediction of $\mathrm{CP}$ content in the residues of A-subset, using equations derived from the B-subset, was more precise than vice-versa. This may result both from the wider range of protein content in the residues of B-subset and/or microbial contamination of a sample (more protein) (Brehm et al., 1997). However, the differences were not high ( $\mathrm{SEP}=1.30-1.71$ vs $0.79-0.87$ ). Decreasing the numbers of samples in the calibration set had no significant effect on the precision of estimation of CP in the study of Reeves et al. (1991).

\section{CONCLUSIONS}

For whole-crop grain silages, crude protein content in the residues after incubation in the rumen can be predicted using NIRS. The best accuracy of prediction was shown when 6 or 9 wavelengths were used in the calibration equations.

\section{REFERENCES}

AOAC, 1995. Official Methods of Analysis. Association of Official Analytical Chemists. $16^{\text {th }}$ Edition. Arlington, VA

Brelım N.M., Hoffman P.C., Peters J.B., Combs D.K., Undersander D.J., 1997. Estimation of crude protein and microbial protein contamination of in situ forage residues by near infrared spectroscopy. J. Dairy Sci. 80, Suppl. 1,217 (Abstr.)

Clark D.H., Lamb R.C., 1991. Near Infrared Reflectance Spectroscopy: A survey wavelength selection to determine dry matter digestibility. J. Dairy Sci. 74, 2200-2205 
IDAS+PC - User's Reference Manual for InfraAlyzer Data Analysis Software, 1989. Revision B, Bran and Lucbbe, Nordstedt (Germany)

Kowalski Z.M., Borowiec F., Pisulewski P.M., Micek P., Ludwin J., 200!. The effect of ensiling and stage of maturity of whole-crop oat on protein degradability in the rumen and intestinal digestibility of rumen-undegraded protein. J. Anim. Feed Sci. 10 (in press)

Nocek J.E., 1988. In situ and other methods to estimate ruminal protein and cnergy digestibility: a review. J. Dairy Sci. 71, 2051-2089

Reeves J.B., Blosser 'T. H., Balde A.T., Glenn B.P., Vandersall J., 1991. Near infrared spectroscopic analysis of forage samples digested in situ (nylon bag). J. Dairy Sci. 74, 882-895

\section{STRESZCZENIE}

\section{Szacowanie zawartości bialka w próbkach po inkubacji w żwaczu in situ metodą NIRS}

Celem badań było sprawdzenie możliwości użycia spektroskopii odbiciowej w bliskiej podczerwieni (NIRS) do szacowania zawartości białka ogólnego w próbkach pozostałości kiszonck z calych roślin zbożowych po inkubacji w żwaczu in situ.

Próbki kiszonck z calych roślin zbożowych (owsa i pszenżyta) zebrane w rożnych fazach dojrzałości (kłoszenie, faza mleczna i mleczno-woskowa), byly inkubowane w żwaczu przetokowanych buhajków przez $2,4,8,16,24,48$ i 72 godziny. Po inkubacji woreczki były płukane i suszone $\left(45^{\circ} \mathrm{C}\right.$, $48 \mathrm{~h}$ ), a w pozostałości oznaczono chemicznie zawartość białka ogólnego ( $\mathrm{N} \times 6.25$ ). Pomiary widma w bliskiej podczerwieni przeprowadzono na suchych i zmielonych (sito $1 \mathrm{~mm}$ ) próbkach pozostałości po inkubacji w żwaczu. Pomiar widma wykonano dwukrotnic, z obrotem naczyńka za pomocą 19 filtrowego spektrofotometru InfraAlyser 450R (Technicon) o zakresie widma 1445*2348 nm. Uśrednione wyniki zapisywano jako log $\mathrm{l} / \mathrm{R}$ (R-reflektancja). Obliczenia statystyczne wykonano za pomocą programu komputerowego IDAS PC współpracującego $z$ aparatem. Równania kalibracyjne wyliczono przy uwzględnieniu 3,6 i 9 długości fal dla zbiorów: wszystkich próbek $(n=126)$, próbek podzbioru $A(n=72,2-16$ godz. inkubacji), próbek podzbioru $B(n=54$, degradacja w żwaczu przez 24-72 h).

Zawartość białka ogólnego w próbkach kiszonek poddanych degradacji w żwaczu może być szacowana za pomocą metody NIRS. Współczynnik korelacji wielokrotnej (R) takiego szacowania wynosił $0,90 \div 0,97$, natomiast standardowy błąd kalibracji (SEC) micścił się w zakresic $0,38 \div 0,41$. Najlepszą precyzję szacowania uzyskano przy zastosowaniu 6 lıb 9 filtrów oraz przy zbiorze kalibracyjnym 126 próbek. 